\title{
Metode Pengering Gabah Aliran Massa Kontinu Dengan Wadah Pengering Horizontal dan Pengaduk Putar
}

\author{
Nusyirwan \\ Jurusan Teknik Mesin, UniversitasAndalas, Padang, SumateraBarat, Indonesia \\ E-mail: nusyirwan@ft.unand.ac.id
}

\begin{abstract}
Abstrak
Peralatan pengeringan yang ada dipasaran mengeringkan massa gabah secara statis. Pengeringan statis gabah dikeringkan dalam massa tertentu dengan jumlah luas wadah tertentu dan tidak bisa ditambah secara secara secara langsung. Proses pengeringan dengan kwantitas yang besar pengeringan harus dilakukan secara dinamis. Yang dimaksud dengan pengeringan secara dinamis adalah massa gabah yang dikeringkan dapat mengalir secara kontinu yaitu massa massa masuk dapat ditambah setiap waktu sedangkan prodak yang dikeringkan dapat dihasilkan setiap waktu juga. Salah satu alat pengering yang memenuhi sarat adalah alat pengering putar atau alat pengering yang dilengkapi dengan peralatan pengaliran massa. Salah satu yang dilakukan adalah pengering dengan wadah berbentuk silinder dengan pengering putar yang dapat mengaduk dan mengalirkan material dari sisi masuk ke sisi keluar dan laju aliran massa dapat diatur sesuai dengan putaran pengaduk. Pengeringan dilakukan dalam dua siklus yang lama waktu pengeringan 60 menit per siklus. Dari hasil pengeringan siklus pertama belum cukup tercapat kadar air yang diinginkan. Massa gabah diumpankan kembali untuk siklus kedua. Pada sklus kedua ini pengeringan telah tercapai dengan kadar air maksimal yang dihilangkan adalah $47 \%$.
\end{abstract}

Kata kunci: $\quad$ Grain mass, Rotary Dryer.

\section{PENDAHULUAN}

Dengan bertambahan penduduk Indonesia yang sangat cepat kebutuhan akan pangan terutama beras semakin meningkat. Faktor yang kontroversial adalah jumlah lahan di Indonesia yang setiap tahun semakin berkurang. Permasaalahan lain yang timbul adalah iklim dengan kelembaban yang tinggi menyebabkan panen sering rusak akibat jamur karena cahaya matahari yang kurang pada musim pada musim hujan. Proses pengeringan padi tidak dapat berjalan secara optimal sehingga menyebabkan pembusukan dan penurunan kualitas beras. Kondisi ini tidak bisa dibiarkan agar para petani tidak mengalami kendala untuk menjemur gabah pada musim hujan tersebut. Untuk itu bantuan teknologi sangat diperlukan untuk mengatasi hal tersebut.

Beberapa cara penjemuran telah dilakukan baik secara tradisional yaitu cara penjemuran dengan menggunakan lantai penjemuran dengan berbagai bentuk lantai atau ditambah alas dan cara mekanisasi seperti tray dryer( dengan rak bertingkat). Peralatan pengering yang ada sekarang adalah massa yang dikeringkan tidak dihasilkan secara kontinu melainkan ditunggu beberapa waktu baru dikeluarkan dari wadah pengering. Pada penelitian sebelumnya prodak yang dihaliskan tidak dialirkan secara kontinu namun ditunggu 10 menit [7]. Salah satu yang diusulkan dalam penelitian ini adalah mekanisme penjemuran dengan wadah horizontal dengan media berbentuk setengah silinder yang dilengakapi dengan agitator (pengaduk). Peralatan yang diusulkan adalah massa gabah dapat bergerak kontiu dan bisa ditambah dan dikurangi pada peride atau siklus tertentu.

\section{TINJAUAN PUSTAKA}

Kelembaban yang tinggi menyebabkan kondisi padi mudah memburuk terutama di daerah yang beriklim tropis. Pada musim hujan pengeringan padi tidak dapat berjalan secara optimal sehingga menyebabkan pembusukan dan penurunan kualitas beras yang berkualitas[2]. Permasaalahan lain adalah kesalahan dalam proses pemilihan alat penggering. Proses pengeringan yang tidak tepat dapat menurunkan mutu gabah sampai mencapai 2,13\%[2].

Pengeringan padi yang dilakukan masyarakat saat ini masih secara manual (konvensional) dengan memanfaatkan energi cahaya matahari atau di jemur sehingga membutuhkan waktu yang lama, sangat tergantung dengan keadaan cuaca, kadar air produk yang dihasilkan tidak seragam, dan kapasitas padi yang dihasilkan terbatas karena membutuhkan tempat yang luas dalam proses pengeringan tersebut serta biaya operasional yang besar[3].

Adapun beberapa jenis alat pengering yang telah ada dipasaran antara lain adalah Flat Bed Dryer, Screen Conveyor, Tunnel Dryer, Tray Dryer dan Drum Dryer. Namun kelemahan pada berbagai alat pengering jenis ini material tidak dibalik secara bergantian sehingga produk yang dihasikan tidak merata. 
Kelemahan lain adalah pada peralatan pengering prodak pengering tidak dihasilkan secara kontinu.

Pengeringan gabah yang dilakukan secara tradisional dilakukan dengan menggunakan alas atau lantai dibawah sinar matahari langsung yang dapat mengurangi kadar air gabah akibat radiasi sinar matahari. Menurut penelitian [3] kadar air yang berkurang dapat mencapai sekitar $20 \%$ dansisanya sekitar $6 \%$ dari kadar air tersebut tidak dapat dikurangi lagi karena kadar air yang tinggal adalah kadar air kesetimbangan.

Untuk mempertahankan berat material hasil pengeringan yang konstan dan mencegah kerusakan mikrobiologi gabah dilakukan berbagai teknik pengeringan gabah untuk mempertahankan kualitas gabah yang dihasilkan. Misalnya menjaga temperatur pengeringan yang tidak tinggi dan laju udara panas yang tidak terlalu besar. Untuk hal tersebut pengeringan tidak mudah dilakukan dalam waktu yang cepat karena dibutuhkan proses pengurangan kadar uap air keudara secara perlahan dan alamiah yang tergantung karakteristik gabah. Untuk melakukan proses pengeringan diperlukan proses yang teliti dan tidak boleh terhenti sampi kadar air dalam material tidak bisa dikurangi lagi. Jika pengeringan dihentikan secara tiba-tiba material yang telah kering dapat kembali menyerap uap air yang ada diudara sehingga material tidak kering sempurna.. Untuk membuang air yang masuk kembali ke material diperlukan energi tambahan yang lebih besar. Keseragaman hasil pruduk proses pengeringan merupakam standar kualitas suatu produk prealatan pengering.

\section{METODE PENELITIAN}

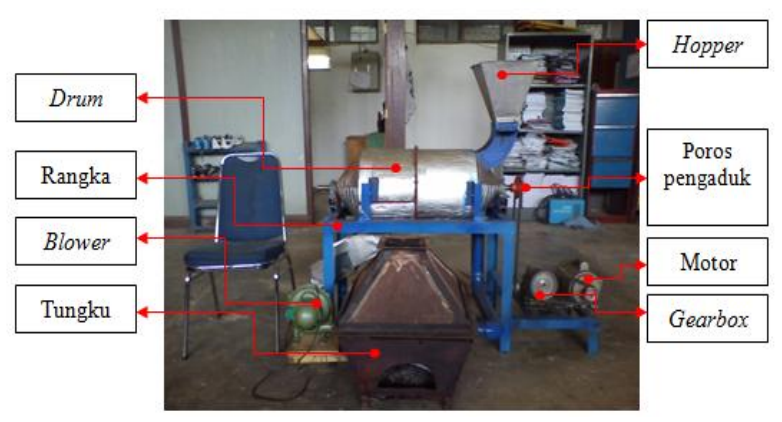

Gambar 3.1. Alat Pengering Padi Tipe Drum Dryer Dengan Mekanisme Pengaduk

\section{Keterangan dan fungsi alat:}

1. Tungku pemanas berguna untuk sumber energi pengeringan sesuai dengan standar pengeringan. Bahan bakar adalah batok kelapa $8 \mathrm{~kg}$ dan segera secara terus menerus ditambah bila temperatur ruangan pengering turun dari $60{ }^{\circ} \mathrm{C}$. Standar penguapan untuk $100 \mathrm{~kg}$ gabah kering sawah menjadi gabah kering giling distandarkan dengan berat air diuapkan tiap $100 \mathrm{~kg}$ gabah basah adalah $=24 \mathrm{~kg}$. Perkiraan kalor penguapan $650 \mathrm{kkal} / \mathrm{kg}$ air $=15.600 \mathrm{kkal}$. Jika batok kelapa digunakan sebagai bahan bakar dari batok kelapa didekati dengan sekam tersebut $20 \mathrm{~kg}$ bahan baku=2.000 $\mathrm{kkal}=40.000 \mathrm{kkal}$. Untuk pengujian $10 \mathrm{~kg}$ gabah kering mengacu keperbandingan standar tersebut diatas.

2. Blower digunakan untuk meniupkan udara panas yang telah dipanaskan pada tungku pemanas.

3. Motor listrik sebagai digunakan memutar pengaduk dengan daya $1 / 4 \mathrm{HP}$.

4. Inverter untuk pengaturan putaran pengaduk.

5. Pengaduk dengan enam buah (6) buah lengan pengaduk yang dipasang pada sudut yang berbeda $90^{\circ}$.

\section{Pengujian Kadar Air dengan Siklus Pengeringan Bertahap}

Pengujian kadar air diasumsikan sama dengan jumlah massa gabah yang hilang akibat proses pengeringan. Jumlah massa gabah yang dumpankan adalah sebanyak $10 \mathrm{~kg}$ dan dialirkan dengan merata kedalam wadah pengering. Lamanya siklus pengeringan adalah selama 60 menit untuk siklus pertama. Semua sampel yang keluar dari peralatan pengering akan ditimbang selama periode ini dan beratnya akan dicatat. Setelah itu akan diumpankan kembali kedalam wadah pengering untuk periode siklus kedua dan akan dilakukan seperti siklus sebelumnya.

Prosedur pengujian yang dilakukan sebagai berikut: (1) Persiapkan alat pengering, padi sebanyak $10 \mathrm{~kg}$. (2) Atur putaran motor menggunakan slide regulator dan ukur putaran poros pengaduk hingga kecepatan $40 \mathrm{rpm}$,50rpm dan $60 \mathrm{rpm}$ menggunakan tachometer.(3) Nyalakan blower dan ukur temperatur untuk udara panas masuk dan keluar menggunakan thermometer. (4) Masukkan padi dari daerah pertama kedalam hopper inlet, kemudian buka pengatur masukan secara perlahan, setelah padi telah masuk seluruhnya tutup kembali pengatur masukan catat temperatur masuk dan keluar padi (5) Hitung waktu padi berada di dalam drum selama 60 menit menggunakan stopwatch. (6) Buka pengatur keluaran pada hopper outlet secara perlahan, setelah padi keluar seluruhnya tutup kembali pengatur keluaran. (7) Timbang berat padi menggunakan timbangan digital kemudian catat hasil penurunan massanya. (8) Lakukan prosedur 4-7 untuk padi dari daerah yang berbeda dengan penambahan waktu 10 menit tiap proses berikutnya hingga masa akhir padi hampir tidak mengalami penurunan(massa padi telah konstan).

\section{Pengujian Optimasi Karakteristik Pengeringan}

Pengujian ini dilakukan untuk mendapatkan karakteristik pengeringan padi yang baik dalam wadah pengering dengan bantuan mekanisme pengaduk putar. Pengaduk putar ini berfungsi untuk mengaduk massa 
gabah dapat teraduk secara merata dan mengalir keluar wadah pengering secara kontinu. Proses ini lakukan untuk putaran pengaduk yang berbeda untuk dilakukan perbandingan waktu pengeringan dengan putaran masing-masing pengaduk. Prosedur pengujian yang dilakukan sebagai berikut : (1) Persiapkan padi sebanyak $10 \mathrm{~kg}$ dan batok kelapa $\pm 9 \mathrm{~kg}$. (2) Atur putaran motor menggunakan slide regulator dan ukur putaran poros pengaduk hingga kecepatan 40rpm menggunakan tachometer.(3) Hidupkan blower dan ukur temperatur di dalam drum hingga mencapai kisaran $60 \quad{ }^{\circ} \mathrm{C}$ menggunakan thermometer. (4) Masukkan padi tersebut kedalam hopper inlet. (5) Hitung waktu padi berada di dalam drum selama 60 menit menggunakan stopwatch. (6) Buka pengatur keluaran pada hopper outlet secara perlahan. (7) Timbang berat padi menggunakan timbangan digital kemudian catat hasilnya. (8) Lakukan prosedur 4-7 untuk padi yang sama dengan penambahan waktu 60 menit tiap proses berikutnya hingga waktu pengeringan seluruhnya mencapai 60 menit. (9) Lakukan prosedur 4-8 untuk kecepatan $50 \mathrm{rpm}$ dan $60 \mathrm{rpm}$ dengan massa padi yang lain dengan prosedur yang sama. Setiap pengujian ini harus mengacu pada standar[ SNI No. 4512.1 -TAN-1998].

\section{Pengujian Keseragaman Hasil Pengeringan}

Pengujian keseragaman pengeringan dilakukan untuk melihat apakah hasil pengeringan padi merata atau tidak. Dengan menggunakan alat pengering padi diharapkan hasil dari pengeringan padi merata karena adanya mekanisme pengaduk yang dipakai pada alat pengering ini. Sehingga padi hasil pengeringan dengan kadar air yang merata akan menghasilkan produk yang baik.

Prosedur pengujian yang dilakukan sebaagai berikut : (1) Persiapkan padi sebanyak $10 \mathrm{~kg}$ dan batok kelapa $\pm 9 \mathrm{~kg}$. (2) Atur putaran motor menggunakan slide regulator hingga kecepatan putaran poros pengaduk $40 \mathrm{rpm} .(3)$ Nyalakan blower dan ukur temperatur di dalam drum hingga mencapai kisaran 60 ${ }^{\circ} \mathrm{C}$ menggunakan thermometer. (4) Masukkan padi ke dalam hopper inlet, kemudian buka pengatur masukan secara perlahan, setelah itu tutup pengatur masukan. (5) Hitung waktu padi berada di dalam drum selama 60 menit.(6) Setelah 60 menit, buka pengatur keluaran pada hopper outlet secara perlahan, setelah padi keluar seluruhnya tutup kembali pengatur keluaran.(7) Hasil pengeringan dibagi menjadi delapan (10) bagian dengan masing-masing bagian akan diukur perbedaan berat masanya dengan melakukan penimbangan berat masing-masing.

\section{Alat Ukur Pengujian}

1. Speed Kontrol Motor: Untuk mengatur kecepatan pengaduk sesuai dengan yang diinginkan

2. Timbangan Digital: menimbang produk hasil pengeringan

3. Stopwatch : untuk mencatat waktu pengeringan
4. Tachometer: mencatat putaran pengaduk

5. Thermometer: mencatat waktu periode pengeringan

6. Gelas Ukur: Mencatat volume gabah hasil produk

\section{Metode Analisis Pengolahan Data}

1. Kadar air

Kadar air adalah perbandingan antara berat air di dalam gabah terhadap berat gabah yang mengandung air tersebut menurut [4].

$$
K_{w}=\frac{m_{w}}{m_{w}+m_{d}}
$$

Keterangan $: K_{w} \quad:$ kadar air dalam padi (\%)

$$
\begin{array}{ll}
m_{w} & : \text { :massa air dalam padi }(\mathrm{kg}) \\
m_{d} & : \text { :massa padi kering }(\mathrm{kg})
\end{array}
$$

2. Massa air yang diuapkan

Untuk menghitung massa air yang diuapkan, dapat menggunakan persamaan sebagai berikut ini :

$$
\Delta m_{w}=\frac{m\left(K_{0}-K_{1}\right)}{1-K_{1}}
$$

Keterangan :

$$
\begin{array}{ll}
\Delta m_{w} & : \text { :massa air yang diuapkan }(\mathrm{kg}) \\
m & : \text { :massa gabah }(\mathrm{kg}) \\
K_{0} & : \text { kadar air awal }(\%) \\
K_{1} & : \text { kadar air yang diharapkan }(\%)
\end{array}
$$

\section{Laju penguapan}

Laju penguapan air sangatlah berpengaruh dalam proses pengeringan, yang menggambarkan bagaimana kecepatan pengeringan tersebut berlangsung. Laju penguapan dinyatakan dengan berat air yang diuapkanp ersatuan waktu (disaat kadar air $\pm 14 \%$ ). Dapat dihitung menggunakan persamaan berikut :

$$
W_{d o t}=\frac{\Delta m_{w}}{T}
$$

Keterangan:

$$
\begin{array}{ll}
W_{d o t} & \text { : laju penguapan air (gr/menit) } \\
\Delta m_{w} & : \text { massa air yang diuapkan (gr) } \\
T & : \text { waktupengeringan (menit) }
\end{array}
$$

4. Lajumassaudarapengeringan

Laju udara pengeringan dapat diketahui dengan persamaan berikut :

$$
M_{d o t}=\frac{W_{d o t}}{H_{2}-H_{1}} .
$$

Keterangan: 
$M_{\text {dot }} \quad$ : laju massa udara pengering

(kg/jam).

$W_{d o t} \quad$ : laju penguapan air $(\mathrm{kg} / \mathrm{jam})$.

$H_{1} \quad$ : kelembaban mutlak udara padakeluaran $\left(\mathrm{kg} / \mathrm{m}^{3}\right)$.

$\mathrm{H}_{2} \quad$ : kelembaban mutlak udara didalam $\operatorname{drum}\left(\mathrm{kg} / \mathrm{m}^{3}\right)$.

5. Debit aliran udara

Debit aliran udara dapat diketahui dengan persamaan berikut :

$$
Q=M_{d o t} \times v
$$

Keterangan $: Q \quad:$ debit aliran udara $\left(\mathrm{m}^{3} / \mathrm{jam}\right)$.

$M_{d o t} \quad$ : laju massa udara pengeringan

$$
\begin{array}{ll} 
& (\mathrm{kg} / \mathrm{jam}) . \\
v & : \text { volume spesifik udara } \\
& \text { pengering }\left(\mathrm{m}^{3} / \mathrm{kg}\right) .
\end{array}
$$

6. Energi pemanasan

Untuk mengetahui energi panas dihasilkan oleh bahan bakar [4].

$$
Q_{b b}=H V f \times m b
$$

Keterangan $: Q_{b b}$ : kalor bahan bakar (Watt/jam).

$$
\begin{aligned}
& H V f \text { : nilai kalor bahan bakar }(\mathrm{kJ} / \mathrm{kg}) \text {. } \\
& m b \quad \text { :massa bahan bakar }(\mathrm{kg}) .
\end{aligned}
$$

Karena pemanasan ini bersifat konveksi maka, energi yang dihasilkan oleh tungku pemanas dapat dihitung dengan menggunakan persamaan :

$$
Q_{m}=h \times A \times\left(T_{1}-T_{2}\right)
$$

Keterangan:

$$
\begin{array}{ll}
h & : \text { koefisien perpindahan panas } \\
& \text { konveksi }\left(\mathrm{W} / \mathrm{m}^{2} \cdot \mathrm{K}\right) . \\
A & : \text { luasan }\left(\mathrm{m}^{2}\right) . \\
T_{1} & : \text { suhu didalam silinder }(\mathrm{K}) . \\
T_{2} & : \text { suhupadasaluranmasuk }(\mathrm{K}) .
\end{array}
$$

Sedangkan energi untuk memanaskan udara pengering dapat dihitung dengan menggunakan persamaan :

$$
Q_{1}=M_{\text {dot }} \times\left(h_{2}-h_{1}\right)
$$

Keterangan :

$Q_{1} \quad$ : energi untuk memanaskan udara (kJ/jam).

$M_{\text {dot }} \quad$ : laju massa udara pengering (kg/jam).

$h_{1} \quad$ : entalpi pada saluran masuk.

$h_{2} \quad$ : entalpi pada drum.

Energi panas yang digunakan untuk penguapan dapat dihitung dengan menggunakan persamaan :

$$
Q_{2}=W_{\text {dot }} \times h f g \text {. }
$$

Keterangan :

$Q_{2} \quad$ : energi untuk menguapkan air (kJ/jam).

$W_{\text {dot }} \quad$ : laju penguapan air $(\mathrm{kg} / \mathrm{jam})$.

$h f g$ : panas laten penguapan air

(kJ/kg air).

7. Efesiensi pengeringan

Efisiensi pengeringan terdiri atas efisiensi pemanasan, efisiensi pemanasan dan efisiensi penggunaan panas total, ini dapat dihitung dengan menggunakan persamaan berikut :

a. Efisiensi penguapan

$$
E_{g}=\frac{Q_{2}}{Q_{1}} \times 100 \%
$$

Keterangan :

$$
\begin{array}{ll}
E_{g} & \text { : efisiensi penguapan }(\%) \\
Q_{2} & \begin{array}{l}
\text { : energi untuk menguapkan air } \\
(\mathrm{kJ} / \mathrm{jam})
\end{array} \\
Q_{1} & \text { : energi untuk memanaskan udara }
\end{array}
$$$$
(\mathrm{kJ} / \mathrm{jam})
$$

b. Efisiensi pemanasan

$$
E_{p}=\frac{Q_{1}}{Q_{m}} \times 100 \%
$$

Keterangan: $E_{p} \quad$ : efisiensi pemanasan $(\%)$

$Q_{m} \quad$ : energi panas dari sumber panas

$$
\text { (kJ/jam) }
$$

$Q_{1} \quad$ : energi untuk memanaskan udara (kJ/jam)

c. Efisiensi penggunaan

$$
E_{k}=\frac{E_{g} \times E_{p}}{100}
$$

Keterangan $: E_{k} \quad$ : efisiensi penggunaan panas total

$E_{g} \quad$ : efisiensi penguapan air (\%) 
$E_{p} \quad$ : efisiensi pemanasan udara (\%)

\section{HASIL DAN PEMBAHASAN}

Pengujian pengurangan massa gabah lus adalah sama dengan jumlah massa air yang dindahkan keudara panas pada proses pengeringan. Panjang wadah pengering adalah $180 \mathrm{~cm}$ dengan jarak $30 \mathrm{~cm}$ dipasang termometer untuk memantau temperatur gabah dan temperatur udara panas. Adapun hasil pengujian dapat dilihat pada gambar 4.1. Pengujian dibagi dalam dua siklus. Satu siklus adalah periode selama 60 menit.

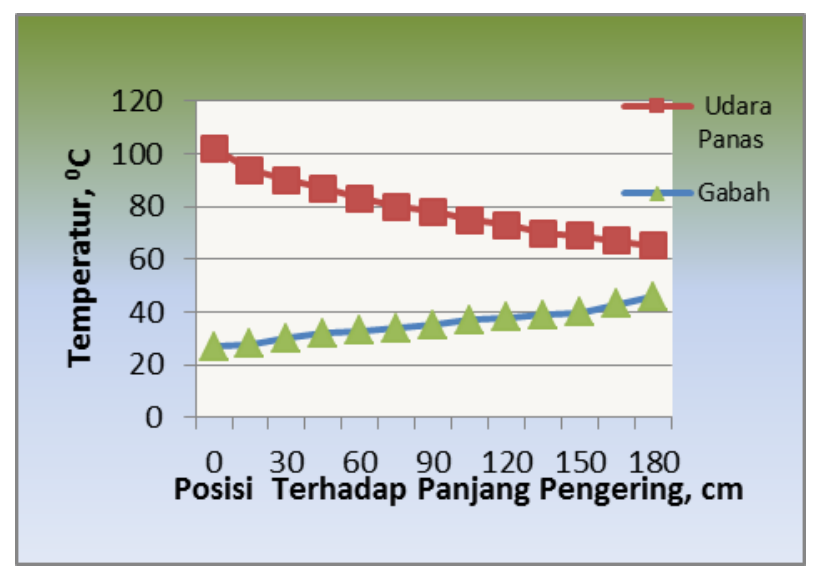

Gambar 4.1. Grafik Temperatur Massa Gabah terhadap panjang pengerin Pada Siklus 1

Dari Gambar 4.1 dapat terlihat bahwa temperatur udara masuk $108{ }^{\circ} \mathrm{C}$ akan turun menjadi $62{ }^{\circ} \mathrm{C}$ karena akan diambil oleh gabah. Sedangkan temperatur gabah meningkat dari $26^{\circ} \mathrm{C}$ menjadi $42^{\circ} \mathrm{C}$.

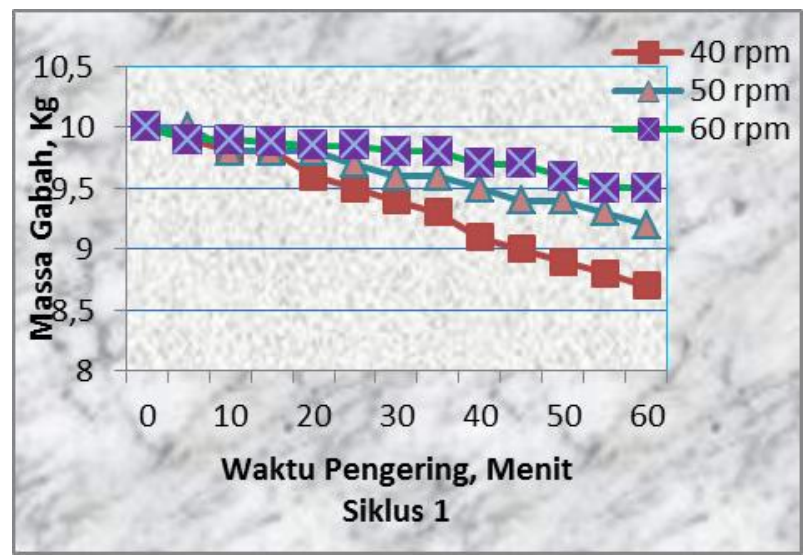

Gambar 4.2. Grafik Penurunan Massa Gabah terhadap Waktu Pengeringan Pada Siklus 1

Dari Gambar 4.2 dapat terlihat bahwa massa gabah turun dari $10 \mathrm{~kg}$ menjadi $8,6 \mathrm{~kg}$ untuk putaran $40 \mathrm{rpm}$. Sedangkan untuk putaran $50 \mathrm{rpm}$ berat gabah turun $9,7 \mathrm{~kg}$ dan putaran $60 \mathrm{~kg}$ turun 9,1 kg. Dari
Siklus 1 terlihat dengan putaran $40 \mathrm{~kg}$ pengurangan berat massa gabah lebih cepat.

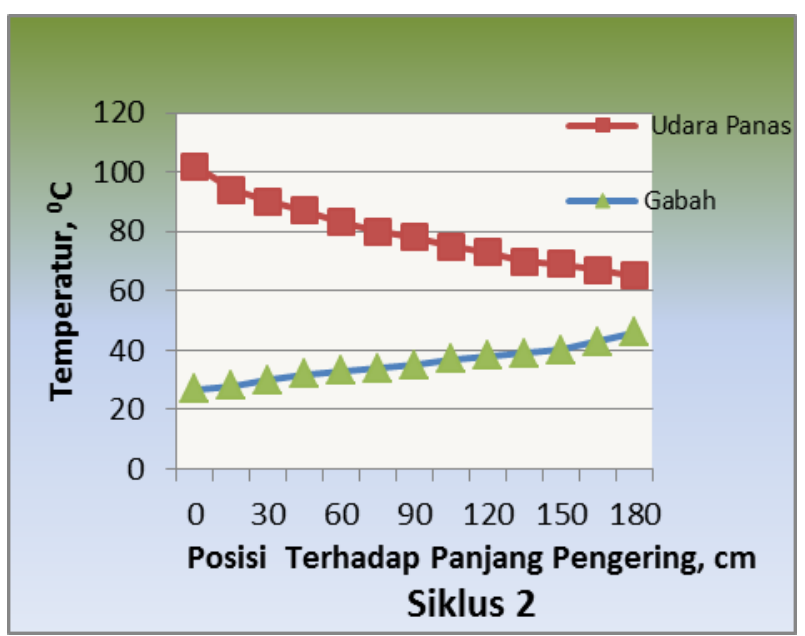

Gambar 4.3. Grafik Temperatur Massa Gabah terhadap panjang pengerin Pada Siklus 2

Dari Gambar 4.1 dapat terlihat bahwa temperatur udara masuk $108{ }^{\circ} \mathrm{C}$ akan turun menjadi $62{ }^{\circ} \mathrm{C}$ karena energi panas akan dindahkan ke gabah. Sedangkan temperatur gabah meningkat dari $26^{\circ} \mathrm{C}$ menjadi $42^{\circ} \mathrm{C}$.

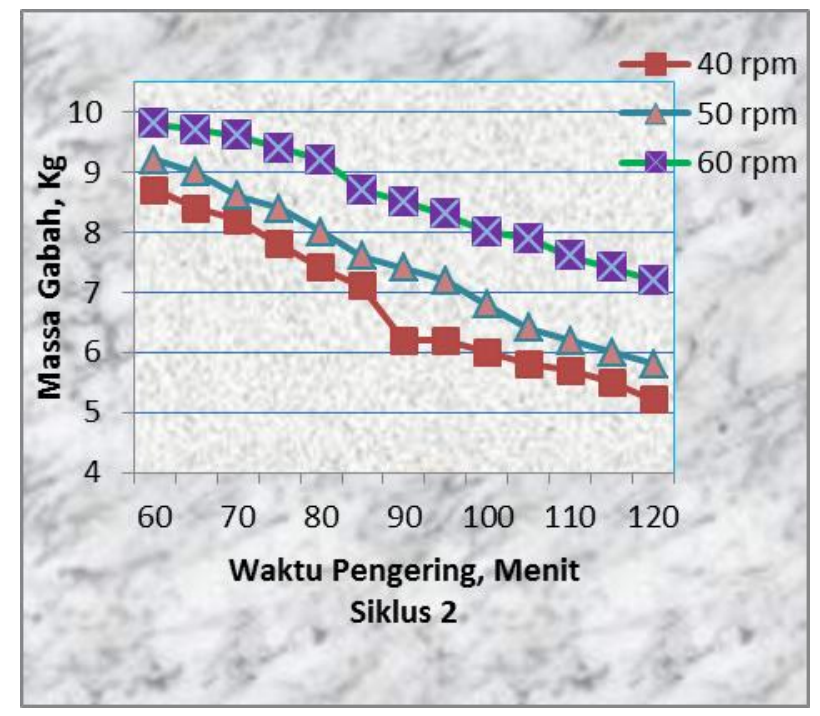

Gambar 4.4. Grafik Penurunan Massa Gabah terhadap Waktu Pengeringan Pada Siklus 2

Dari Gambar 4.4 dapat terlihat bahwa massa gabah turun dari $10 \mathrm{~kg}$ menjadi $5.3 \mathrm{~kg}$ untuk putaran $40 \mathrm{rpm}$. Sedangkan untuk putaran $50 \mathrm{rpm}$ berat gabah turun $5,8 \mathrm{~kg}$ dan putaran $60 \mathrm{~kg}$ turun $7,21 \mathrm{~kg}$. Dari Siklus 2 terlihat dengan putaran $40 \mathrm{~kg}$ penngurangan berat massa gabah lebih cepat. 


\section{Hasil Pengujian Optimasi Karakteristik Pengeringan}

Pengujian karakteristik pengeringan dilakukan untuk menentukan berapa lama pengurangan massa gabah setiap satu siklus pengeringan. Pada gambar 5.1 terlihat pada siklus pengeringan 1 (satu) atau siklus pertama selama 60 menit massa gabah terbesar pada putaran $40 \mathrm{rpm}$ pengaduk hanya $15 \%$, sedangkan pada putaran $50 \mathrm{rpm}$ baru 5,8 \% sedangkan pada putaran $60 \mathrm{rpm} \mathrm{5,1 \%} \mathrm{berdasarkan} \mathrm{ini} \mathrm{pengeringan} \mathrm{pada}$ siklus 1 harus diulangi dengan memasukan produk kembali sebagai massa umpan atau massa masuk.

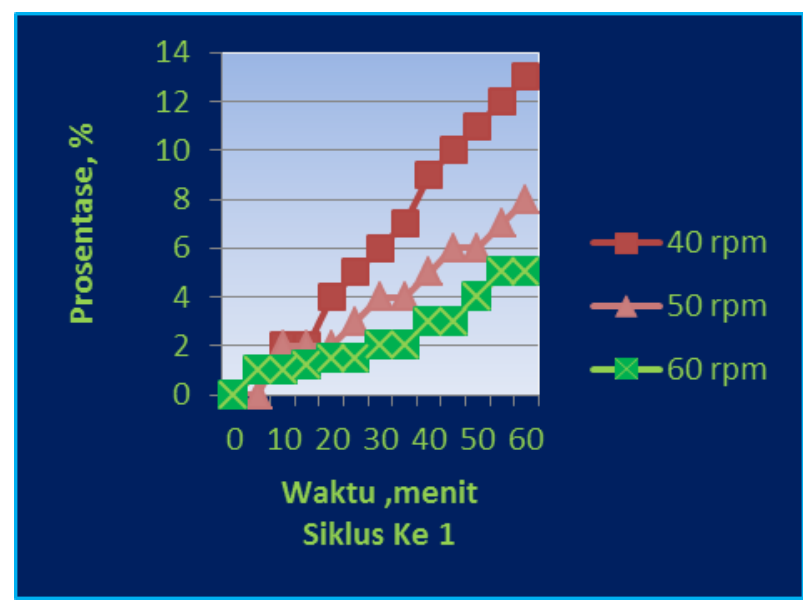

Gambar 5.1. Grafik Prosentase Penurunan Massa Gabah Terhadap Waktu Pengeringan Pada Siklus 1

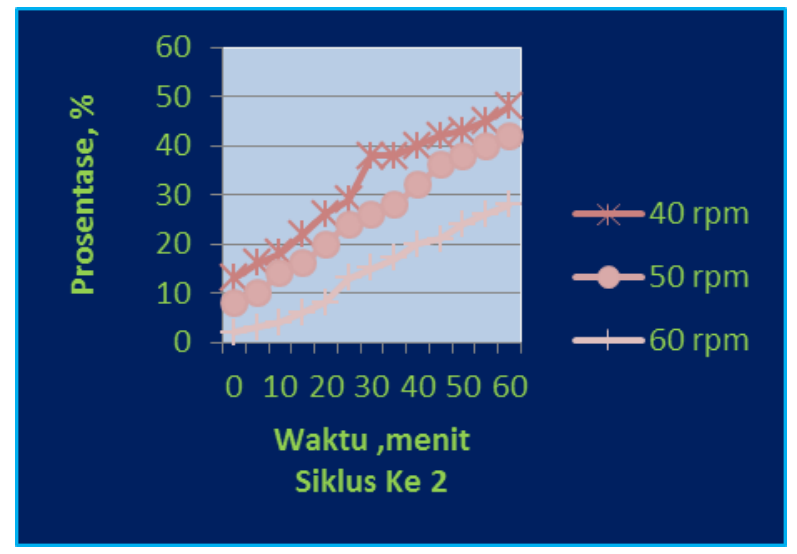

Gambar 5.2. Grafik Prosentase Penurunan Massa Gabah Terhadap Waktu Pengeringan Pada Siklus 1

Pada gambar 5.2 terlihat pada siklus pengeringan Siklus 2 (dua) selama 60 menit massa gabah terbesar pada putaran pengaduk $40 \mathrm{rpm}$, sudah mencapai $47 \%$, pada putaran $50 \mathrm{rpm}$ baru $43 \%$ sedangkan pada putaran $60 \mathrm{rpm} 28 \%$. Berdasarkan ini pengeringan pada siklus 2(dua) prosentase pengeringan telah tercapai dengan baik karena pada $40 \mathrm{rpm}$, dan tidak perlu diulangi tahap pengeringan selanjutnya. Pengeringan yang demikian sudah memenuhi standar [ SNI No. 4512.1 -TAN-1998], dengan kwalitas gabah yang tidak rusak.

\section{KESIMPULAN}

Kesimpulan yang dapat diambil dari penelitian pengujian alat pengering padi tipe wadah berbentuk silinder dan pengaduk putar untuk aliran massa kontinu diperolehnya hasil karakteristik pengeringan sebagai berikut :

1. Persentase kandungan massa pada siklusm 1(satu) belumdapat dapat mengeringkan massa gabah secara total dari $46 \%$ massa uap air yang terkandung dalam gabah hanya maksimal $15 \%$ pada putaran $40 \mathrm{rpm}$ maka massa gabah dikeringkan kembali dengan mengumpankan gabah pada siklus ke dua.

2. prosentase penurunan massa gabah pada siklus pengeringan Siklus 2 (dua), selama 60 menit massa gabah terbesar pada putaran pengaduk $40 \mathrm{rpm}$, sudah mencapai $47 \%$. Berdasarkan ini pengeringan pada siklus 2(dua) prosentase pengeringan telah tercapai dengan baik karena pada $40 \mathrm{rpm}$, dan tidak perlu diulangi tahap pengeringan selanjutnya. Pengeringan yang demikian sudah memenuhi standar [SNI No. 4512.1 -TAN-1998], dengan kwalitas gabah yang tidak rusak.

- Padi, kadar air, dan laju pengeringan sangat dipengaruhi oleh putaran poros pengaduk. Semakin tinggi putaran poros pengaduk maka semakin cepat penurunan massa dan kadar air padi, serta semakin tinggi laju pengeringan yang terjadi.

- Putaran poros pengaduk yang memenuhi syarat pengeringan berdasarakan persentase kadar air $14 \%$ dalam padi adalah $35 \mathrm{rpm}$ dalam waktu 30 menit dengan kapasitas $8 \mathrm{Kg}$.

- Hasil pengeringan padi menggunakan drum dryer dengan mekanisme pengaduk menghasilkan persentase keseragaman pengeringan $86,6 \%$.

- Berdasarkan waktu yang dibutuhkan untuk mengeringkan padi dalam $1 \mathrm{~kg}$ alat pengering tipe drum dryer lebih unggul dan efisien waktu pengeringannya, yaitu waktu yang dibutuhkan untuk mengeringkan $1 \mathrm{~kg}$ padi adalah 3,75 menit $/ \mathrm{kg}$.

\section{UCAPAN TERIMA KASIH}

Penelitian dilakukan pada Laboratorium Perancangan Elemen Mesin Jurusan teknik Mesin Universitas Andalas. Ucapan Terima kasih disampaikan pada pihak pimpinan Jurusan Teknik yang dapat memfasilitasi penelitian ini dalam pengadaan peralatan yaitu satu buah set-up pengujian mesin pengering yang dilengkapi dengan instrumen pengukurannya.

\section{DAFTAR PUSTAKA}

[1]. Sidik, Mulyo. 2006.Prospect of Rice Production and Food Security in East Asia, Di dalam Peningkatan Daya Saing Beras Nasional Melalui Perbaikan Kualitas., Lokakarya Nasional. Jakarta: 13-14 September 2006. 


\section{KerjasamaPerum BULOG dengan FATETA}

IPB.

[2.]. Soponronarit, S. Luangmalawat, P. Prachayawarakon,S. Nathakaranakule, A. 2007. Effect of Temperature on Drying Characteristics and Quality of Cooked Rice. Bangkok: Journal of Food Egineering. LWT 41, 716-723.

[3]. Athajariyakul, S and Leephakreeda, T. 2006. Fluidized Bed Paddy Drying in Optimal Conditions Via Adaptive Fuzzy Logic Control.Bangkok: Journal of Food Engineerig.75, 104-114.

[4] K, D. Mustofa. 2011. Pengaruh Waktu Pengeringan Terhadap Kadar Air Gabah Pada Mesin Pengering Gabah Kontinyu Kapasitas $100 \mathrm{Kg}$ dan Daya 1890 W.UI : Jurusan Teknik Mesin Politeknik Negeri Jakarta.

[5] Perry, Robert H. Perry's.Chemical Enginerrs' Handbook Sixth Edition. USA: McGraw-Hill

[6] Sofwan, Irham. 2008 Perancangan, Pembuatan dan Pengujian Alat Pemisah Partikel Padat Dengan Ses iSeperasi $50 \mathrm{~cm}$ dan Plat Penampug BerbentukS etengah Bola. Indonesia: UniversitasAndalas.

[7] White, Frank M. 2003. Fluid Mechanic 4th Edition. USA: Mc. Graw-Hill. 